\title{
TINNITUS SOUND THERAPY WITH A MOBILE APPLICATION: CASE STUDY
}

Contributions: A Study design/planning B Data collection/entry C Data analysis/statistics C Data analysis/statistics D Data interpretation E Preparation of manuscrip F Literature analysis/search $\mathrm{G}$ Funds collection

\section{Justyna Kutyba ${ }^{1 \mathrm{ABDEF}}$, W. Wiktor Jedrzejczak ${ }^{1 \mathrm{DEF}}$, Danuta Raj-Koziak ${ }^{1 \mathrm{BF}}$, Elżbieta Gos ${ }^{1 C D E}$, Piotr H. Skarzynski ${ }^{1,2,3 G}$}

${ }^{1}$ World Hearing Center, Institute of Physiology and Pathology of Hearing, Kajetany, Poland

${ }^{2}$ Heart Failure and Cardiac Rehabilitation Department, 2nd Faculty of Medicine, Medical University of Warsaw, Warsaw, Poland

${ }^{3}$ Institute of Sensory Organs, Kajetany, Poland

Corresponding author: Justyna Kutyba, MSc, Teleaudiology and Screening Examinations Department, Institute of Physiology and Pathology of Hearing, Mokra 17 St.;

05-830 Kajetany, Poland; email: j.kutyba@ifps.org.pl

\begin{abstract}
Background: Every year more people suffer from tinnitus. Therapy for the condition requires a comprehensive approach to the patient. Despite the existence of many treatment methods, none is $100 \%$ effective. After a physician has excluded organic diseases, it is standard practice to try sound therapy. The aim of this study was to evaluate the effectiveness of sound therapy by means of a free mobile application ReSound Tinnitus Relief in a patient with very troublesome tinnitus.

Case study: The patient, a 34-year-old woman, reported very troublesome tinnitus, described as a constant, non-pulsating ringing sound felt "inside the head". The patient was offered sound therapy using a widely available application installed on a mobile phone. Progress of the therapy and changes in tinnitus perception were evaluated using two standardized questionnaires: the Tinnitus Handicap Inventory and the Tinnitus Functional Index. Results from both questionnaires showed that overall tinnitus annoyance decreased after 3 and 6 months of use.

Conclusions: The data demonstrate that the use of sound therapy on a mobile app can provide satisfactory results, at least in this patient. However, it is not possible to say that such sound therapy will bring relief to all patients. Nevertheless, it is an option that a doctor can offer to their patient. A further study is needed on a large group of people to confirm whether it is possible to replace conventional sound generators with mobile solutions.
\end{abstract}

Key words: tinnitus $\bullet$ sound therapy $\bullet$ habituation

\section{TERAPIA DE SONIDO PARA EL TINNITUS A TRAVÉS DE UNA APLICACIÓN MÓVIL - ESTUDIO DE CASO}

\section{Resumen}

Introducción: Cada año, el número de personas que sufren de tinnitus aumenta. La terapia del tinnitus requiere un enfoque integral del paciente. Aunque hay muchos métodos de tratamiento, ninguno de ellos es cien por ciento efectivo. Cuando el médico descarta las enfermedades orgánicas, es una práctica clínica estándar incluir al paciente en la terapia de sonido. El objetivo de este estudio fue evaluar la eficacia de la terapia de sonido realizada con una aplicación móvil gratuita en un paciente con tinnitus muy molesto.

Estudio de caso: La paciente, una mujer de 34 años, informó de un tinnitus muy cansado, descrito como un sonido no pulsante que sentía en su cabeza. A la paciente se le ofreció terapia de sonido utilizando una aplicación móvil de acceso público instalada en su teléfono móvil. Los progresos de la terapia y los cambios en la percepción del tinnitus se evaluaron mediante dos cuestionarios normalizados: Tinnitus Functional Index y Tinnitus Handicap Inventory. Los resultados de ambos cuestionarios mostraron que la irritación general por el tinnitus disminuyó al cabo de de 3 y 6 meses de uso.

Conclusiones: El estudio demostró que la terapia de sonido aplicada mediante la aplicación móvil ha dado al paciente resultados satisfactorios. Sin embargo, no se puede decir que esta terapia sea efectiva para todos los pacientes. De todas maneras, es una opción más que el médico puede ofrecer a los pacientes. Se necesitan más investigaciones, especialmente sobre un grupo grande de personas, para confirmar que es posible sustituir los generadores de sonido convencionales por soluciones móviles.

Palabras clave: tinnitus • terapia de sonido • habituación 


\title{
ЗВУКОВАЯ ТЕРАПИЯ УШНЫХ ШУМОВ С ПОМОЩЬЮ МОБИЛЬНОГО ПРИЛОЖЕНИЯ - ОПИСАНИЕ СЛУЧАЯ
}

\begin{abstract}
Аннотация
Введение: С каждым годом количество людей, страдающих шумом в ушах, увеличивается. Лечение тиннитуса требует комплексного подхода к пациенту. Не смотря на то, что существует много различных способов лечения, ни один из них не дает сто процентного положительного результата. После того, как врач исключает органические заболевания, обычной практикой является назначение лечения с помощью звуковой терапии. Целью данного исследования является оценка эффективности звуковой терапии, проводимой с помощью бесплатного мобильного приложения у пациента с очень надоедающим шумом в ушах.

Описание случая: Пациентка (34 года, женщина) обратилась с мучающим ее шумом в ушах, который она описывала как не пульсирующий звук, ощущаемый в голове. Пациентке была предложена звуковая терапия с использованием общедоступного мобильного приложения, установленного на мобильном телефоне. Эффект от терапии и изменения в ощущении шума в ушах оценивались с использованием двух стандартизированных анкет: Tinnitus Functional Index и Tinnitus Handicap Inventory. Результаты обеих анкет показали, что общее раздражение, вызванное шумом в ушах, уменьшилось после 3 и 6 месяцев применения.

Выводы: Исследование показало, что примененная звуковая терапия с использованием мобильного приложения принесла пациенту удовлетворительные результаты. Однако, нельзя сказать, что эта терапия окажется эффективной для каждого пациента. Тем не менее, можно рассматривать ее как еще один вариант лечения, который врач может предложить пациентам. Необходимы дальнейшие исследования на большей группе пациентов для подтверждения того, что можно использовать мобильными приложения вместо обычных генераторов шума.
\end{abstract}

Ключевые слова: шум в ушах • звуковая терапия • привыкание

\section{TERAPIA DŹWIĘKIEM SZUMÓW USZNYCH PRZY UŻYCIU APLIKACJI MOBILNEJ - STUDIUM PRZYPADKU}

\section{Streszczenie}

Wprowadzenie: Każdego roku zwiększa się liczba osób cierpiących z powodu szumów usznych. Terapia szumów usznych wymaga kompleksowego podejścia do pacjenta. Pomimo że istnieje wiele metod leczenia, żadna nie jest w stu procentach skuteczna. W sytuacji gdy lekarz wykluczy choroby organiczne, standardową praktyką kliniczną jest objęcie pacjenta terapią dźwiękiem. Celem niniejszego badania była ocena skuteczności terapii dźwiękiem prowadzonej za pomocą bezpłatnej aplikacji mobilnej u pacjenta z bardzo dokuczliwymi szumami usznymi.

Studium przypadku: Pacjentka, 34-letnia kobieta, zgłosiła bardzo męczący szum w uszach, opisany jako niepulsujący dźwięk odczuwany w głowie. Pacjentce zaoferowano terapię dźwiękiem za pomocą ogólnodostępnej aplikacji mobilnej zainstalowanej w telefonie komórkowym. Postęp terapii i zmiany w odczuciu szumów usznych oceniono za pomocą dwóch znormalizowanych kwestionariuszy: Tinnitus Functional Index oraz Tinnitus Handicap Inventory. Wyniki obu kwestionariuszy wykazały, że ogólna irytacja szumów usznych zmniejszyła się po 3 i 6 miesiącach stosowania.

Wnioski: Badanie wykazało, że zastosowana terapia dźwiękiem za pomocą aplikacji mobilnej przyniosła u pacjentki satysfakcjonujące efekty. Nie można jednak stwierdzić, że terapia ta będzie skuteczna w przypadku każdego pacjenta. Niemniej jest to kolejna opcja, którą lekarz może zaproponować pacjentom. Konieczne są dalsze badania, zwłaszcza na dużej grupie osób, aby potwierdzić, że możliwe jest zastąpienie konwencjonalnych generatorów dźwięku rozwiązaniami mobilnymi.

Słowa kluczowe: szum w uszach • terapia dźwiękiem • habituacja

\section{Abbreviations}

MML Minimal Masking Level

RTR Resound Tinnitus Relief

TFI Tinnitus Functional Index

THI Tinnitus Handicap Inventory

UCL Uncomfortable level

\section{Introduction}

More and more people suffer from tinnitus every year. The World Health Organization defines tinnitus as hearing sound while there is no external signal [1]. The sounds can be described as ringing, squeaking, or humming but also clicking or bubbling. Tinnitus can be quiet or very loud, and its location can be in the ears or inside the head [2-4]. In some people the constant unwanted sound can cause anxiety, depression, or concentration problems $[5,6]$. Tinnitus therapy requires a comprehensive approach to the patient [7]. Despite the existence of many treatment methods, none of them is $100 \%$ effective $[8,9]$. Current tinnitus therapy aims to make the tinnitus as unobtrusive as possible [10]. After a physician has excluded organic disease, it is standard practice to apply sound therapy $[2,11]$.

According to the American Tinnitus Association, sound therapy is the use of an external acoustic signal to change the perception of tinnitus or how the patient reacts to the tinnitus [12]. Sound therapy, like others, does not cure tinnitus, but can significantly reduce tinnitus annoyance [13]. There are many different sound-based tinnitus therapies, but masking and tinnitus habituation are the most common [14-16]).

In the 1980s, sound was mainly used to mask tinnitus [17]. This method involves exposing the patient to an external sound source which is louder than the tinnitus so that the sound partially or completely hides the tinnitus [18]. 
Masking can be used temporarily in acute, intense tinnitus, but it does not produce a lasting therapeutic effect $[10,19]$.

In 1990s, sound habituation therapy was described [20]. This therapy is based on increasing the background noise level of the environment and is intended to reduce the contrast in auditory pathways between the tinnitus and the background. After a while, the tinnitus blends into the background and is no longer perceived as annoying $[20,21]$.

In sound therapy, the signal can be delivered by different devices, e.g. an audio player, but it is most convenient to use broadband noise generators or bedside sound generators [22]. For certain groups of patients, no special devices are used, the only recommendation being to surround oneself with enriched ambient sounds for as long as possible $[10,23]$. Recently, it has been observed that patients undergoing therapy are increasingly using mobile applications instead of conventional devices $[24,25]$. Unfortunately, there is little information in the literature on the effectiveness of sound therapy using mobile applications $[25,26]$.

The current study tried to fill this gap by assessing the performance of a single patient using the free mobile application ReSound Tinnitus Relief (RTR). The main advantages of this work over what has been done to this date in this area is the use of standardized research tools (two specialized questionnaires for tinnitus) and a long observation period of 6 months, which is significantly more than in previous studies, e.g. [26].

The aim of this study was to evaluate the effectiveness of sound therapy by means of a free mobile application in the case of a 34-year-old woman with very troublesome tinnitus. The subjective evaluation of the application by the patient and the effectiveness of the therapy were also analyzed.

RIGHT EAR

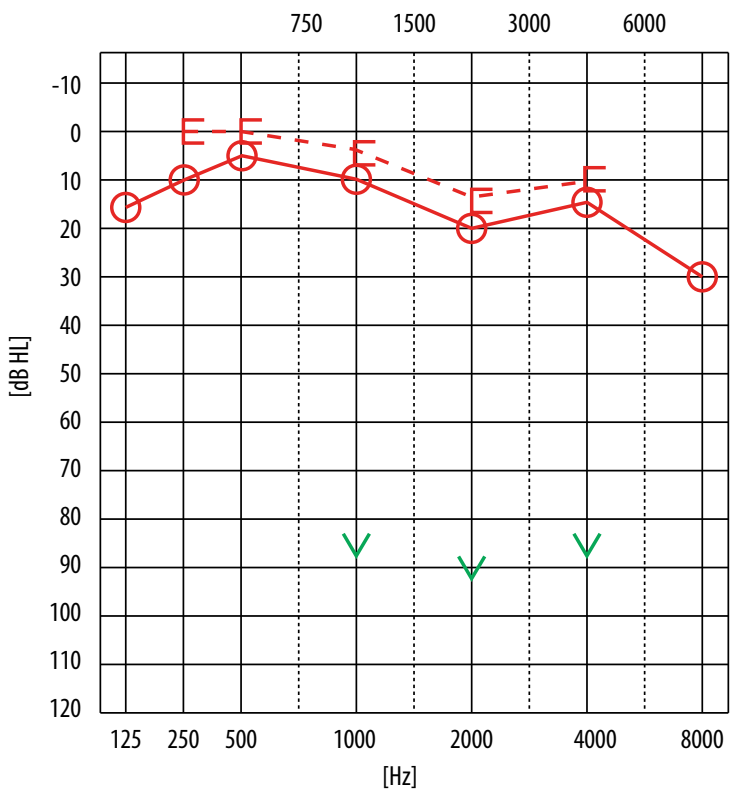

\section{Case description}

A 34-year-old woman reported very troublesome tinnitus. In the interview it was found that the tinnitus had appeared suddenly, with no specific cause or event. The patient described the sound as a constant ringing heard "inside the head". The degree of annoyance as assessed with the Tinnitus Handicap Inventory questionnaire was 80 points, which means that the tinnitus had a 'catastrophic' impact on the patient's functioning. The tinnitus was not accompanied by dizziness or hyperacusis. Before the visit to our clinic, the patient had been undergoing pharmacological treatment for 3 months (Neurovit, Nootropil, Histigen); however, this treatment did not affect her tinnitus sensation or general health. Physical examination showed no oral, nose, throat, or ear pathology. Otoscopic imaging showed no visible changes. Acoustic reflexes were present on both sides. On the basis of pure tone audiometry, normal hearing in both ears was found according to the BIAP classification (Bureau International d'Audiophonologie). The uncomfortable level (UCL) for each ear was also determined, and were also within the normal range (Fig. 1).

The results of impedance audiometry revealed bilateral type A tympanograms in both ears with preserved middle ear muscle reflexes at all frequencies except $4 \mathrm{kHz}$. Eustachian tube function was normal in both ears. Tinnitus characteristics determined using a Madsen audiometer showed that the tinnitus was heard by the patient in the head and had a frequency of about $1 \mathrm{kHz}$ and intensity of $10 \mathrm{~dB}$. The minimum level of tinnitus masking was $30 \mathrm{~dB}$.

\section{Method}

The patient was offered sound therapy using the widely available application ReSound Tinnitus Relief installed on a mobile phone.

Figure 1. Results of pure tone audiometry for air and bone conduction, including UCL, for the right and left ears 


\section{ReSound Tinnitus Relief (RTR)}

The RTR application was developed by the ReSound company in partnership with tinnitus experts [25]. The application is designed to support patients during sound therapy and facilitate this form of treatment. It incorporates methods such as sound therapy, breathing, relaxation, and targeted meditation. RTR has an extensive sound library divided into three categories:

- Environment: sounds of nature (e.g. crickets, birdsong) and sounds of everyday life (e.g. traffic, dishwasher, highway)

- Music: relaxation music

- Therapeutic sounds: white, pink, brown, and purple noise.

Currently there are more than 30 sound files in the library. The application is also equipped with a 'sound mixer'. This function allows patients to create their own sounds according to their individual preferences $[27,28]$.

\section{Tools}

Evaluation of progress and changes in tinnitus perception used two standardized questionnaires: the Tinnitus Handicap Inventory and the Tinnitus Functional Index.

The Tinnitus Handicap Inventory (THI) was developed in the USA by Newman et al. in 1996 [29] as a questionnaire to assess the problems caused by tinnitus. It incorporates three subscales: functional, emotional, and catastrophic reactions. The maximum score is 100 points, with the higher the score, the more serious the discomfort. Adaptation of the questionnaire to Polish was carried out in 2018 by specialists from the Institute of Physiology and Pathology of Hearing [30].

The Tinnitus Functional Index (TFI) is a questionnaire created in 2012 by researchers from the USA and New Zealand [31], and was validated in Polish in 2016 [32]. TFI is used to assess tinnitus annoyance and its impact on the patient's life in eight areas: intrusiveness, sense of control, cognition, sleep, auditory, relaxation, quality of life, and emotional. TFI is also used to evaluate changes occurring as a result of treatment. The response points range from 0 to 10 . The patient can achieve a maximum of 100 points, and again the higher the score, the greater the tinnitus nuisance.

\section{Procedure}

\section{At the hospital.}

- A psychological consultation: factors affecting tinnitus and the psychological strategies of coping with the problem were discussed.

- Audioprosthetic consultation: the principles of sound therapy were discussed, instructions for using a mobile application were presented, and the application was installed on the patient's mobile phone.

\section{At home.}

The patient used ReSound Tinnitus Relief for 6 months according to the following recommendations:
- time: the patient decided herself when to use the application and for how long, but no less than 30 minutes per day.

- the way of listening to the sounds: sounds were heard through the phone's speaker (so-called free field).

- the level of the emitted signal: sounds emitted from the application should not completely mask the patient's tinnitus. The sounds should be slightly quieter.

Data on the course of the therapy was collected by mail 3 and 6 months after leaving the hospital ward.

\section{Results}

Descriptive statistics for the THI and TFI results were prepared to gauge the possible differences in tinnitus intensity experienced by the patient over three periods (before, 3 months, and 6 months after).

\section{Changes in tinnitus as measured with THI}

Tinnitus intensity level as measured by global THI score during hospitalization was 80 points (catastrophic tinnitus); after 3 months of use it decreased to 72 points (severe), and after 6 months it was 46 points (moderate). A similar effect was observed for the subscales (functional, emotional, and catastrophic) where the scores gradually decreased. The results obtained for all the THI subscales and the global score are presented in Figure 2.

\section{Changes in tinnitus as measured with TFI}

The tinnitus level as measured by the global TFI result during hospitalization was 73 points (a very big problem); after 3 months of application it decreased to 67.2 (a big problem); and after 6 months it was 48 points (a moderate problem).

The subscales indicated that 3 months after using the application, relaxation and general quality of life was better. After another 3 months, annoyance was reduced on all subscales compared to before the therapy began.

\section{Discussion}

Treatment of tinnitus patients should aim to make the tinnitus as inconspicuous as possible for the patient [33]. The main task of the physician is to get the patient out of a vicious cycle of tension and gently induce them to ignore the internal sound [10]. For this purpose, sound therapy is often used [21].

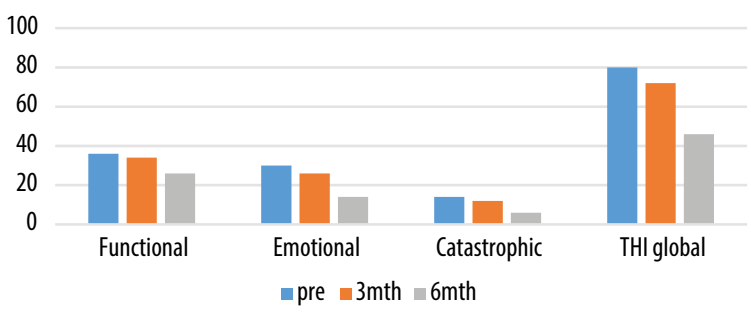

Figure 2. The number of points scored on three subscales and the overall result of the Tinnitus Handicap Inventory questionnaire 


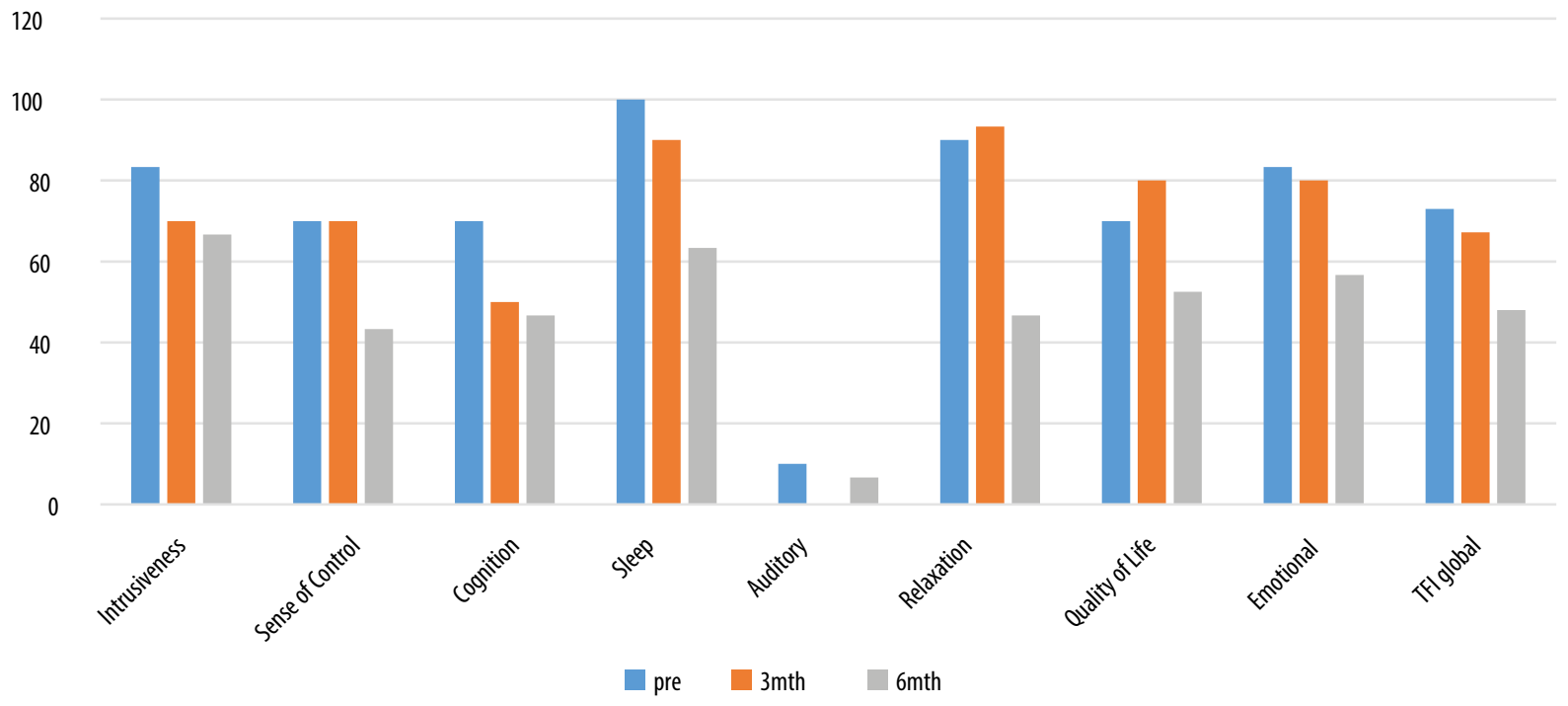

Figure 3. The number of points scored on eight subscales and the overall result of the Tinnitus Functional Index questionnaire

The aim of this study was to evaluate the effectiveness of sound therapy carried out with a commonly available mobile application. The results, as shown by the data from both questionnaires, showed that the overall tinnitus annoyance decreased after both 3 and 6 months of use. It is notable that the results obtained from both tools were consistent, which increases the reliability of the finding. The TFI questionnaire also showed that the functioning of the patient in different spheres of life had improved. After 6 months of therapy, a reduction in negative tinnitus effects was observed on all measured subscales.

The results presented here should encourage tinnitus sufferers to try such applications. A recent study showed that $75 \%$ of such people did not use tinnitus management applications [34]. Furthermore, the most common reason was simply lack of awareness of the existence of tinnitus management applications.

To date there is limited data objectively evaluating the ReSound Tinnitus Relief application. One study looked at a particular subgroup of tinnitus sufferers, cochlear implant users. It focused on the acceptability of the signals as presented by the implant. The study showed that for $90 \%$ of participants the therapy was satisfactory [in reducing tinnitus] and the most acceptable sound was rain and waves on rocks.

The results here show that a mobile application can be an effective therapy in reducing the annoyance of tinnitus. The patient reported that she fully accepted the device and was satisfied with it. However, it should be emphasized that each patients reacts in a different way to treatment [35], meaning that one method may be beneficial for one patient but completely unacceptable and ineffective for another. Thus, it is not possible to say that the RTR system will work for every patient. Nevertheless, it is another option that a doctor can offer their patient. In future, a larger study should be carried out to ascertain whether it is possible to replace conventional sound generators with mobile solutions.

\section{References}

1. KrugEG, World Health Organization. Hearing loss due to recreational exposure to loud sounds: a review. 2015. Available from http:// apps.who.int/iris/bitstream/10665/154589/1/9789241508513_eng. pdf?ua=1. Accessed 24 Oct 2019.

2. Baguley D, McFerran D, Hall D. Tinnitus. Lancet, 2013;382(9904): 1600-07.

3. Langguth B, Kreuzer PM, Kleinjung T, De Ridder D. Tinnitus: causes and clinical management. Lancet Neurol, 2013;12(9): 920-30.

4. Henry JA, Dennis KC, Schechter MA. General review of tinnitus: prevalence, mechanisms, effects, and management. J Speech Lang Hear Res, 2005;48(5):1204-35.

5. Kaluzny W, Durko T, Pajor A. Ocena wpływu szumów usznych na stan emocjonalny chorych na podstawie Kwestionariusza Ogólnego Stanu Zdrowia Goldberga. Otolaryngol Pol, 2004;(58):851-6.
6. Landgrebe M, Langguth B. Tinnitus and psychiatric co-morbidity. In: Textbook of Tinnitus. New York: Springer Verlag; 2011:491-2.

7. Milner R, Lewandowska M, Ganc M. Niespecyficzne metody wykorzystywane w terapii szumów usznych: przegląd wybranych technik. Nowa Audiofonologia, 2014;(3):20-25.

8. Hesse G. Evidence and evidence gaps in tinnitus therapy. GMS Curr Top Otorhinolaryngol Head Neck Surg. 2016;15:Doc04.

9. Langguth B, Goodey R, Azevedo A, Bjorne A, Cacace A, Crocetti A, Del Bo L, De Ridder D, Diges I, Elbert T, Flor H, Herraiz C, Ganz Sanchez T, Eichhammer P, Figueiredo R, Hajak G, Kleinjung T, Landgrebe M, Londero A, Lainez MJ, Mazzoli M, Meikle MB, Melcher J, Rauschecker JP, Sand PG, Struve M, Van de Heyning P, Van Dijk P, Vergara R. Consensus for tinnitus patient assessment and treatment outcome measurement: Tinnitus Research Initiative meeting, Regensburg, July 2006. Prog Brain Res, 2007;166:525-36. 
10. Bartnik G. Szumy uszne: fakty istotne klinicznie. Mag Otolaryngol, 2003;3:57-72.

11. Niedzielski A, Kedzierawska S. Szumy uszne-przegląd aktualnej literatury. Nowa Audiofonologia, 2017;6(4):9-15.

12. American Tinnitus Association. Sound Therapies. Available from https://www.ata.org/managing-your-tinnitus/treatment-options/ sound-therapies. Accessed 24 Oct 2019.

13. Traynor R. The marriage of Bluetooth hearing to smart phones. Hearing International. Available from https://hearinghealthmatters. org/hearinginternational/2014/marriage-bluetooth-smart-phones/. Accessed 22 May 2019

14. Del Bo L, Baracca G, Forti S, Norena A. Sound stimulation. In: Textbook of Tinnitus. New York: Springer Verlag; 2011:597-604.

15. Jastreboff PJ, Hazell JW. A neurophysiological approach to tinnitus: clinical implications. Br J Audiol, 1993;27(1):7-17.

16. Roberts L, Bosnyak D. Auditory training in tinnitus. In: Textbook of Tinnitus. New York: Springer Verlag; 2011:563-73.

17. Vernon JA, Meikle MB. Tinnitus masking: unresolved problems. Ciba Found Symp, 1981;85:239-62.

18. Szymanska E, Bartnik G, Karpiesz L, Borawska B, Skarzynski H, Hesse G. Terapia dźwiękowa jako terapia wspomagająca leczenie szumów usznych. Audiofonologia, 2004;26:185-8.

19. Hazell JW, Wood SM, Cooper HR, Stephens SD, Corcoran AL, Coles RR, Baskill JL, Sheldrake JB. A clinical study of tinnitus maskers. Br J Audiol, 1985;19(2):65-146.

20. Jastreboff PJ. Phantom auditory perception (tinnitus): mechanisms of generation and perception. Neurosci Res, 1990;8(4):221-54.

21. Jastreboff $P$, Jastreboff M. Tinnitus retraining therapy. In: Tinnitus: Theory and Management. 2004:295-309.

22. Czyzewski A. Interdyscyplinarne ujęcie problemu szumów usznych i wynikające z niego technologie elektronicznego wspomagania diagnostyki i terapii. Audiofonologia, 2004;25:27-34.

23. Pajor A, Durko M. Szumy uszne: jak daleko jesteśmy od rozwiązania problemu. Terapia, 2015;11-12:42-49. Available from https://terapia.com.pl/publ/id,142636,ed,290. Accessed 24 Oct 2019.

24. Wise K, Ma E. Clinical presentation of tinnitus and a review of, and evidence base for, tinnitus applications. Perspect ASHA Spec Interest Groups, 2016;1(7):43-56.
25. Henry JA, Thielman E, Zaugg T, Kaelin C, Choma C, Chang B, Hahn S, Fuller B. Development and field testing of a smartphone “app" for tinnitus management. Int J Audiol, 2017;56(10):784-92.

26. Tyler RS, Owen RL, Bridges J, Gander PE, Perreau A, Mancini PC. Tinnitus suppression in cochlear implant patients using a sound therapy app. Am J Audiol, 2018;27(3):316-23.

27. ReSound Tinnitus Relief. App Store. Available from https://apps. apple.com/us/app/resound-tinnitus-relief/id928432517. Accessed 18 Sept 2019.

28. Piskosz, M. (2017, June). ReSound Relief: A comprehensive tool for tinnitus management. AudiologyOnline, Article 20353. Retrieved from www.audiologyonline.com

29. Newman CW, Jacobson GP, Spitzer JB. Development of the Tinnitus Handicap Inventory. Arch Otolaryngol Head Neck Surg, 1996;122(2):143-8.

30. Skarzynski PH, Raj-Koziak D, Rajchel JJ, Pilka A, Wlodarczyk AW, Skarzynski H. Adaptation of the Tinnitus Handicap Inventory into Polish and its testing on a clinical population of tinnitus sufferers. Int J Audiol, 2017;56(10):711-5.

31. Henry JA, Griest S, Thielman E, McMillan G, Kaelin C, Carlson KF. Tinnitus Functional Index: development, validation, outcomes research, and clinical application. Hear Res, 2016;334:58-64.

32. Wrzosek M, Szymiec E, Klemens W, Kotyło P, Schlee W, Modrzyńska M. Polish translation and validation of the Tinnitus Handicap Inventory and the Tinnitus Functional Index. Front Psychol. 2016;7.

33. Searchfield GD, Durai M, Linford T. A state-of-the-art review: personalization of tinnitus sound therapy. Front Psychol, 2017;8: 1599.

34. Sereda M, Smith S, Newton K, Stockdale D. Mobile Apps for Management of Tinnitus: Users' Survey, Quality Assessment, and Content Analysis. JMIR Mhealth Uhealth, 2019;23;7(1):e10353.

35. Cima RFF, Mazurek B, Haider H, et al. A multidisciplinary European guideline for tinnitus: diagnostics, assessment, and treatment. HNO, 2019;67(1):10-42. 